\title{
LOYALTY AND PRIVATE EMPLOYMENT: THE RIGHT OF EMPLOYERS TO DISCHARGE SUSPECTED SUBVERSIVES*
}

MANY private employers have followed the lead of governmental employers, federal, ${ }^{1}$ state, ${ }^{2}$ and local, ${ }^{3}$ and have instituted formal programs for screening their employees' loyalty to the United States. And other private employers, although not initiating formal programs, have simply discharged employees suspected of being disloyal.5 The natural antipathy of employers toward suspected subversives has been translated into such action by world developments

*The Editors wish to acknowledge their obligation to the Louis S. Weiss Fund, Inc. The Weiss Fund made a gift to Yale University in memory of Louis S. Weiss, '15, for a study, in the Law School, of loyalty and security programs affecting employment. The research on which this Comment is based was largely made possible by that grant. The responsibility for this Comment is, of course, the Editors'.

1. On loyalty programs for federal employees, see, in general, Emerson \& Helfeld, Loyalty Among Government Employees, 58 YAlE L.J. 1 (1948); Richardson, Thic Federal Entoloyee Loyalty Program, 51 Cor. L. Rev. 546 (1951); Bailey v. Richardson, 182 F.2d 46 (D.C. Cir. 1950), aff'd without opinion, 341 U.S. 918 (1951). Sce also Barth, The Loyalty of Free Men (1951); Bidde, The Fear of Freedom (1951); Emerson \& Haber, Civil Liberties in the United States 528 et seq. (1952); Gehlhorn, Security, Loyalty and Science (1950); Weyl, The Batrle Against Dis" LOYALTY (1951).

2. The programs of several states are discussed in The StATES ANd Subversion (Gellhorn ed. 1952). See also Chamberdain, Loyalty and Legislative Action (1951); Byse, A Report on the Pennsylvania Loyalty Act, 101 U. of PA. L. REv. 480 (1953); Wieman v. Updegraff, 344 U.S. 183 (1952). For the closely related subject of state loyalty measures for licensed professions, see Brown \& Fassett, Loyalty Tests for Admission to the Bar, $20 \mathrm{U}$. OF CHX. L. Rev. 480 (1953).

3. See, e.g., Horowitz, A Report on the Los Angeles City and County Loyalty Prograns, 5 Stan. L. Rev. 233 (1953); Mowitz, Michigan: State and Local Altack on Subversion in The States and Subversion 184 (Gellhorn ed. 1952); Exrerson \& Hayer, op. cit. supra note 1, at 578; Garner v. Board of Public Works of Los Angeles, 341 U.S. 716 (1951).

4. For an analysis of many of these programs, see NAtional Industrual Conference Board, Industrial Security : Conbaating Subversion and Sabotage (1952). Most of these programs include the screening of prospective employees as well as present cmployees and the issues involved are similar; but the scope of this Comment is restricted to discharge measures.

5. See cases cited notes 54, 56-7, 60-1, 98-108 infra.

6. See Government measures affecting private employment cited note 95 infra. And see United Electrical, Radio \& Machine Workers of America, C.I.O. v. Lilienthal, 84 F. Supp. 640 (D.D.C. 1949); Munitions Board, Standards for Plant Protection 16 (Dep't Def. 1950).

7. See, e.g., Kingston Cake Co., 97 N.L.R.B. 1445 (1952) ; In the Matter of GambleSkogmo, Inc., 75 N.L.R.B. 1068 (1948); Administrative Rulings of NLRB General Counsel, Case No. 72 (March 30, 1951), 27 Labor REL. Rep. (Ref. Man.) 1510 (1951). Many labor unions have their own loyalty programs. See, e.g., Communist DominstroN of Certain Unions, Sen. Doc. No. 89, 82d Cong., 1st Sess. (1951); Weinstock v. 
and pressure from the Government, ${ }^{6}$ labor unions, ${ }^{7}$ management associations, ${ }^{8}$ consumer groups, ${ }^{9}$ and veterans' organizations. ${ }^{10}$

Comparatively little information is available on the formal procedures used to check on the loyalty of employees in private industry. Some employers make use of the files of the House Un-American Activities Committee, or similar state committees, or the facilities of state or local police anti-subversive units. ${ }^{11}$ Some hire investigators to conduct their own field investigations ${ }^{12}$ or subscribe to the loyalty investigating services of private agencies. ${ }^{13}$ And many employers require employees to fill out questionnaires divulging their affiliations, or require an affidavit of non-membership in organizations on the Attorney General's list. ${ }^{14}$ But the great bulk of information on loyalty is probably obtained less formally. ${ }^{15}$ Employers can simply direct

Ladisky, 197 Misc. 859, 98 N.Y.S.2d 85 (Sup. Ct. 1950). These are aided by the noncommunist affidarit requirement of the Taft-Hartley Act. Labor Mfanagement Relations Act of 1917, $\$ 9$ (h), 61 STAT. 146 (1947), 29 U.S.C. $\$ 159$ (h) (Supp. 1952); Greenwald, Non-Communist Affidazits: Taft-Hartley Sousd and Fury, 12 La. L. Rev. 407 (1952).

8. See, e.g., National Industrial Conference Boarn, op. cit. supra note 4; U.S.

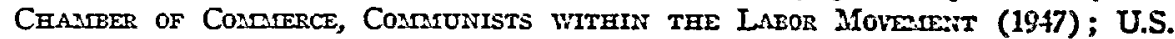

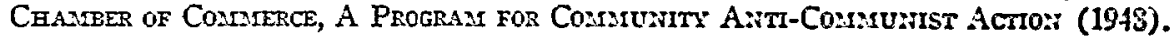

9. For many examples, see MIrLIER, THE JudGes AND the JUdGed (1952).

10. The most notorious instigator has been the American Legion. For an example of the power of the Legion, see N.Y. Times, May 23, 1952, p. 1 ; Eurgssors \& HasEn, op. cit. sispra note 1 , at 578 .

11. See Barth, op. cit. supra note 1 , at 63 ot scq.; House Consuriter on Ui-

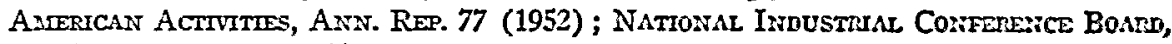
op. cit. stpra note 4 , at 55 .

12. Ibid. Many special agents of the FBI have been lured to jobs in private industry where they can put their anti-subversive training to work as directors of private loyalty programs. Lowenterat, The Federal Bureau of Investigation 353 et seq. (1950); Business Week, July 20, 1946, p. 19.

13. American Business Consultants, Inc., was organized by a group of ex-FBI agents to conduct loyalty investigations for private employers. This same organization publishes an anti-communist newsletter, Countcrattack, and was the publisher of Rcd Cliansels. See MIILER, op. cit. supra note 9, at 61 ct seq., for a discussion of this organization. Dun \& Bradstreet Corp., with main office in New York City and branch offices throughout the country, undertakes to make loyalty investigations for employers on a subseription contract basis.

14. National Industrial Conference Board, op. cit. sispra note 4, at 52 et scq.; see note 127 infra.

15. For a general discussion of the procedures and sources of information for private loyalty programs, see NATMonal Industrial ConfERENCE BoAnd, op. cit. supra note 4, at 55 . The methods are summarized as:

"1. Making inquiries by correspondence including the use of form letters. . . .

2. Making inquiries through telephone contacts.

3. Using services of outside investigators and non-company fact finding agencies.

4. Conducting field investigations by company investigators.

5. Mlaking inquiries through local and national law enforcement agencies." See also How You Can Find Out About a Man's Subversize Affliations Before Hiring Him, Public Relations News, Aug. 9, 1948, p. 1. 
inquiries to personal references or prior employers. ${ }^{10}$ Moreover, they often become aware of facts relative to their employees through chance: newspaper or magazine reports may link an employee with a subversive group; or an employee may be called to testify before one of the numerous Government investigating committees and may even claim the Fifth Amendment as a ground for not testifying.

Where an employee is actually found guilty of an overt act of disloyalty to the Government, no problem faces the employer. Criminal conviction effectively serves to terminate the employment relationship. ${ }^{17}$ But where there is only suspicion of disloyalty, the employer must either retain the individual on his payroll or take affirmative action to discharge him. Continued employment of the suspected worker may seem undesirable in the employer's eyes for a variety of reasons: the employer may find it utterly repugnant to have in his employ a person who is not "one hundred percent American"; he may be engaged in war production and may fear that such an individual might sabotage his plant; he may be engaged in one of the media of communication and may fear that the employee will distort information or attempt by innuendo to influence public opinion; he may face present or potential unrest in his plant arising from the reluctance of other employees to work beside a "red"; or he may face possible loss of public patronage as a result of his tolerance of such an individual.

From the viewpoint of the suspected employee, however, discharge on disloyalty grounds has very serious consequences. Once a man is fired for such a reason, his opportunities for further employment are extremely limited. Prospective employers customarily check prior employers and are not likely to hire anyone whose loyalty has been questioned. Furthermore, the very publicity often accompanying such a discharge-especially where pro* voked by such a publicized event as testimony before an investigating committee-may further injure the employee's reputation. Thus an individual may suffer irreparable injury without ever having an opportunity to prove his loyalty to the United States. An employer may interpret the expression of minority political beliefs as indicative of subversion. Or the employee may have unwittingly loaned his name to an organization not knowing it was a communist front. Should an innocent individual be injured by discharge on grounds of suspected disloyalty, he may, of course, bring an action for defamation against the employer. ${ }^{18}$ But a prudent employer can make it very difficult

16. The Federal Loyalty Review Board has changed its prior contrary rule and will now report to inquiring private employers the fact of an adverse decision on an employee or the fact that the employee left Government employ before his screening was completed. FLRB, Memo. No. 45, July 26, 1949.

17. The criminal statutes are collected in The States and Subversion, App. (Gellhorn ed. 1952); Lewis, Laws Relattwg to Espionage, Sabotage, etc. (1952). See also EMERSon \& HABER, op. cit. supra note 1, at 458 et seq.; Dennis v. United States, 341 U.S. 494 (1951).

18. See the statement of the arbitrator note 103 infra. Some courts have held that accusations of communism, subversion, or disloyalty are per se defamatory. Sce, e.g., 
for a discharged employee to win such an action by being careful to limit both the nature and publication of his charges. ${ }^{10}$

In view of the serious nature of these problems faced by both employer and employee, each party should be aware of his own rights in regard to discharge on grounds of suspected disloyalty. At common law, in the absence of a contract, a private employer has an absolute right to discharge anyone in his employ without cause. ${ }^{20}$ A growing social recognition of a worker's

Spanel v. Pegler, 160 F.2d 619 (7th Cir. 1947) ; Wright v. Farm Journal, 153 F.2d 976 (2d Cir. 1947). But other courts disagree. See, e.g., Keefe v. O'Brien, 116 N.Y.S.2d 286, 288 (Sup. Ct. 1952), 2S Sт. JorN's L. REv. 374 (1953), where the court said:

"To hold that calling one a communist is slander would unwittingly trap the unwary, for nothing would please communists better than to enable them to institute suits for damages promiscuously, regardless of ultimate outcome. It has been amply demonstrated that it is part of communist doctrine and strategy to make the courtroom its forum for propaganda purposes. ... [T] he court will take judicial notice of the cold war now existing between our form of government and communism. Our safety is therefore best served by an exposure of communists and communism. It is far better, therefore, to allow free play of our emotions in dealing with persons whom we believe to be communists rather than to seal the lips of people who might be frightened into silence and suppression lest use of the word "communist' should per se force upon them costly litigation."

There are apparently no reported cases deciding whether ascusations of "doubt as to loyalty" or being "a poor security risk," for example, are defamatory. But cf. Matson v. Margiotti, 371 Pa. 1S8, S8 A.2d $\$ 92$ (1952) (statement in letter from State Attorney General to District Attorney regarding subordinate's alleged communist activities which were alleged to make her a security risk held libelous per se but privileged). The numerous cases are collected in Notes, 51 A.L.R. 1071 (1927), 171 A.L.R. 709 (1947).

The injured party may also have an action against an informer. Sce Foltz v. Moore McCormack Lines, 189 F.2d 537 (2d Cir. 1951) (one maliciously giving information to FBI may be sued for libel by one injured thereby). Cf. Van Knorr y. Afiles, $60 \mathrm{~F}$. Supp. 962 (D. Mass. 1945), remanded for dismissal for lack of jurisdistion, 156 F.2d 287 (1st Cir. 1946) ; Barile v. Fisher, 94 N.Y.S.2d 346 (Sup. Ct. 1949); Mratson v. Margiatti, sispra.

19. Truth is, of course, a defense to a defamation action. And such actions are usually tried to a jury. See, generally, Prosser, Tonts 777 et seq. (1941). For some of the problems of defending such an action, see Utah Farm Bureau Federation v. National Farmers Union Service, 198 F.2d 20 (10th Cir. 1952) ("communist dominated"). And for an interesting recent discussion of the problem of proving publication, see Mims $v$. Ietropolitan Life Ins. Co., 200 F.2d S00 (5th Cir. 1952) (employee claimed he was discharged for refusal to contribute to Sen. Taft's campaign and that the alleged gruund fur discharge-inefficiency-was defamatory).

20. See Odell v. Humble Oil \& Refining Co., 201 F.2d 123 (10th Cir. 1953) and eases therein cited. For an interesting variation, see Harmon v. United Mine Workers of America, 166 Ark. 255, 266 S.W. S4 (1924), where a discharged employee surd his union for prevailing upon his employer to discharge him after expelling him from the union for being a member of the Ku Klux Klan. In affirming dismissal the court said: "There can be no damages resulting to an employee on account of a discharge from an employment at will. The motive of the employer in discharging him is immaterial, and cannot be questioned. The discharge may have been inspired by a bad motive, for the legal right to determine an employment at will is absolute in either the employer or the employee." Id. at $258,266 \mathrm{~S} . \mathrm{W}$. at $\mathrm{S5}$. 
"property right" in his job, however, has resulted in state and federal statutes placing some restrictions on this hitherto unlimited power. ${ }^{21}$ And labor unions, by collective bargaining contracts, have further circumscribed management's discretion to fire workers. These statutes and agreements were not generally drafted to meet the problem of loyalty discharges. But they provide the only possible restrictions upon a private employer's absolute right to discharge employees suspected of disloyalty. As such, they represent the only "rights" available to the suspected employee.

\section{State Statutes}

State statutes place varying limitations on the permissible substantive grounds for discharge of employees. ${ }^{22}$ Two common types could be inter. preted as placing some restrictions on private loyalty measures: the Fair Employment Practices acts, presently in force in about a quarter of the states $;^{23}$ and statutes, in effect in about half the jurisdictions, which pro-

21. On an employee's right to his job, see, generally, Rowland, THe Legal ProTECTION OF THE WORKER'S JOB (1937); Frank, The Right to Work, 6 IND. \& LAv. Rex. Rev. 247 (1952); Lenhoff, The Right to Work: Here and Abroad, 46 Irr. L. REv. 669 (1951).

22. In addition to the types of statutes discussed in notes 23 and 24 infra: Massnchusetts prohibits discrimination on account of age between 45 and 65 ; Louisiana makes it illegal to discriminate on account of age under 50 unless an approved pension plan is in effect; eight states (Iowa, Ky., Me., Mass., N.M., N.Y., Ohio, Wash.) prohibit discharge because of membership in militia, national guard, or similar organization; three (N.M., Ohio, Wis.) require reinstatement of employees returning from military service (with broad exceptions) and prohibit discharge of reinstated employees within one year except for cause; two (Mass., Miss.) prohibit discharge because of absence for, or activities on, a jury ; twelve states (Calif., Kan., La., Mass., Minn., Nev., N.D., Okla., Ore., Pa., R.I., Utah) prohibit discrimination for testifying or making complaint to certain specified state agencies, usually the Wage and Hour Board; about two-thirds of the states have provisions in some way similar to the federal labor relations law aimed at prevention of discrimination in hiring or firing because of union membership or activities.

Contractual limitations also are imposed: A few states deny validity to a personal service contract running more than two years; several states provide that a contract for employment even for a specified term is terminable by the employer for willful breach or habitual neglect of duty, or for continued incapacity; several states also codify the common law by providing that employment for no specified term is terminable at the will of either party; and about two-thirds of the states limit the right to contract with regard to membership or non-membership in labor unions.

23. Fourteen states have some form of such statute (Cal., Colo, Conn., Ill., Ind, Mass., Neb., N.J., N.M., N.Y., Ore., R.I., Wis., Wash.). The eleven broadest of these are summarized in Hearings before Subcommittee on Labor and Labor-Mantgement Rclations of the Committee on Labor and Public Welfare on S.1732 and S.551, 82d Cong,, 2d Sess. 380-3 (1952). See also CAL. LABOR Code $\$ \$ 1735,1777.6$ (Deering, Supp. 1951); Its. Stat. ANN. \$§ 29-17-24, 29-24a-q (Smith-Hurd, 1936); Nez. Rev. StAT. \$48-215 (1943). See, generally, Graves, Anti-Discrminination Legiszation in the Amentcan States (1948); Murray, The Right to Equal Opportunity in Employment, 33 CaLr. 
hibit employer interference with an employee's right to vote or political activity. ${ }^{24}$ But the only decisions thus far have held the protection of such statutes unavailable to persons discharged on disloyalty grounds.

Fair Employment Practices acts generally prohibit employers from asling employees questions which might indicate their race, religion, creed, or national origin. ${ }^{25}$ The New York Committee has held, however, that questions about membership in organizations on the Attorney General's list do not violate that state's act. ${ }^{26}$ And none of the states has interpreted its statute to restrict in any way the discharge of suspected subversives.

Statutes prohibiting employer coercion of employee political activities appear on their face to be a more formidable hurdle to private loyalty programs. But in Lockheed Aircraft Corp. v. Superior Court of Los Angeles County, the

L. Rev. $3 \& 8$ (1945) ; Roper, Discrimination in Industry, 5 ImD. \& LAv. REL Rer. 585 (1952).

A few of these statutes do not restrict all employers, and a few preseribe no sanetion but merely state a public policy. All of these statutes prohibit discrimination on account of race, creed, color, ancestry, or national origin. New Jersey adds to these discrimination because of liability for military service, Mrassachusetts adds age, and Oregen adds se: and union membership. These statutes generally also prohibit discrimination against employees for opposing practices condemned by the acts.

24. Cal., Colo., Conn., Fla., Kan., Ky., Mid, Minn., Miss, MIo., Miont., Neb., N.Y., Ohio, Okla., Pa., S.C., S.D., Texas, Utah, W. Va., Wis., Wyo. Although varying considerably, these statutes generally make it a penal offense for an employer to interiere with the vote of his employees. See, e.g., Wro. Conp. Sr.tr. Axr. § 31-2317 (1945):

"Employers not to interfere with political rights of employees.-It shall be unlawiul for any employer to make, adopt, enforce or attempt to enforce any order, rule, regulation or policy forbidding or preventing any employee from becoming a candidate for public office or for a position on any public board or commission or to malse, adopt, enforce or attempt to enforce any order, rule, or regulation controlling or attempting to control such employee's vote on any question at any public election, or in any public positivn or board or in any ofice to which such employee may be appointed or elected."

Five states have considerably broader provisions. Louisiana and Missouri have statutes similar to that of California. See note 29 infra. Mirss. Cone Arz. $\$ 5335$ (1942) pruvides:

"Social, civil and political rights of employees protected. Any corporation doing business in this state shall be liable to a penalty of two hundred and fifty dollars for every unlawful interference with the social, civil, or political rights of any of its agents or employees, and the same may be recovered by suit, to be brought by the injured party." S.C. CODE OF LAwS $\$ 16-559$ (1952) provides:

"Whoever shall assault or intimidate any citizen because of pulitical opinions or the exercise of political rights and privileges guaranteed to every citizen of the United States by the Constitution and laws thereof or by the Constitution and laws of this State, or, for such reason, discharge such citizen from employment or occupation or eject such citizen from rented house or land or other property shall be deemed guilty of a misdemeanor. ..."

25. See Hearings, supra note 23 , at $3 \mathrm{SO}-3$.

26. See Nate, Inquiries is New York About Subversize Mcmbership, 28 Lav. ReE. REP. (Ref. Man.) 96 (1951).

27. 28 Cal.2d 481, 171 P.2d 21 (1946). 
Supreme Court of California held that one of the most comprehensive of such state statutes did not prohibit an employer from discharging employees whose loyalty to the United States had not been established to his satisfaction. ${ }^{28}$ The statute prohibits employers from adopting or enforcing any rule or policy "controlling or directing, or tending to control or direct the political activities or affiliations of employees," or from coercing or influencing or attempting to coerce or influence employees "through or by means of threat of discharge or loss of employment to adopt or refrain from adopting or following any particular course or line of political action or activity."20 The court reasoned that this wording was not intended to protect any individual or group advocating the overthrow of the Government by force or violence. "On the contrary, the words 'politics' and 'political' imply orderly conduct of government, not revolution." 30 Thus in the court's view, since subversion is not within the realm of protected political activity, discharge because of suspectod disloyalty is not within the area proscribed by the statute.

28. Lockheed Aircraft Corp. discharged eighteen employees because it did not have sufficient information to satisfy itself as to their loyalty. These employees sted for wrongful discharge, relying on the California statute. When Lockheed's demurrer was overruled it brought an action for a writ of prohibition against the court to restrain furm ther proceedings on the ground that the statute was unconstitutional. Lockheed claimed that the section imposed an unjustifiable limitation on its right to contract and that it interfered with management's free speech. Moreover, they contended that, even if constitutional, the statute was penal and provided no civil right of action. The court held that the statute did create a civil right of action, but also held that "we find nothing in the section to prevent an employer engaged in producing vital war materials from dis* charging an employee who advocates the overthrow of our government by force or viou lence or whose loyalty to the United States has not been established to the satisfaction of the employer." Lockheed Aircraft Corp. v. Superior Court of Los Angeles County, 28 Cal.2d 481, 485, 171 P.2d 21, 24 (1946). As interpreted, the court held the statute constitutional. Cf. Santiago v. People of Puerto Rico, 154 F.2d 811 (1st Cir. 1946). In affirming the conviction of an employer under a similar Puerto Rican statute for discharging an employee because of his affiliation with the Popular Democratic Party, the court said "neither the act nor the Supreme Court of Puerto Rico gives the slightest intimation that a property owner may be deprived of his right to protect his property from the destructive acts of his employees." Id. at 813.

29. Cal. Labor Code $\$ \$ 1101-2$ (Deering, 1943) :

"1101. Rule, regulation or policy as to political activities or affiliations. No employer shall make, adopt or enforce any rule, regulation, or policy :

(a). Forbidding or preventing employees from engaging or participating in politics or becoming candidates for public office.

(b). Controlling or directing, or tending to control or direct the political activities or affiliations of employees.

"1102. Coercing or influencing political activities of employees. No employer shall coerce or influence or attempt to coerce or influence his employees through or by means of threat of discharge or loss of employment to adopt or follow or refrain from aclopting or following any particular course or line of political action or political activity."

30. Lockheed Aircraft Corp. v. Superior Court of Los Angeles County, 28 Cal.2d 481, 485, 171 P.2d 21, 24 (1946). 
Although state statutes may provide no substantive obstacles to discharge on loyalty grounds, certain statutes limiting the procrdures which may be used to effectuate discharge may place some restrictions on private loyalty programs. $^{31}$ For example, Ohio and Nevada prohibit firing or disciplining of an employee upon report of a company detective, spotter, or spy where the reason involves a question of integrity or honesty, unless a hearing is accorded. ${ }^{32}$ A Minnesota statute prohibits an employer's spying on employees" activities "in the exercise of their legal rights." 33 New York prohibits the fingerprinting of employees by employers, subject to certain exceptions. And about half the states make it a criminal offense for an employer to blacklist an employee or to maintain a blacklist. ${ }^{35}$ But no cases have yet held these provisions applicable to employer loyalty measures. ${ }^{33}$

Most of these statutes were enacted in the past to deal with then-current problems completely unrelated to employee loyalty. It is therefore to be expected that courts and boards will be reluctant to construe them as limiting the right of private employers to police the loyalty of their employees. But a

31. Procedural restrictions other than those discusscd notes $32-5$ inffra include the following: four states (Me, Mass., Pa., Wis.) provide that if an employer requires notice of quitting from an employee he must give comparable notice of firing to such employee; nine (Fla, Ind., Kan., Mo., Jiont., Neb., N.M., Olila, Texas) require that upon request an employer must give a discharged employee a statement of his service and the reason for discharge.

32. OnIo Gev. Code Ann. $\$ 129 \$ 6-1$ (Page, 1937) ; Nev. Cossp. L.lws $\$ 2770$ (Hillyer, 1929).

33. Minn. Stat. Anv. $\$ 179.12(5)(1946)$.

34. N.Y. LAEOR LAW $\$ 201-a$.

35. See, e.g., Colo. Stat. ANN, c. 97, \$§ \$S-9 (1935); Conw. Rev. StıT. \$ \&531 (1949). Several states also provide a civil remedy for blacklisting, including treble damage suits and recovery of attorney fees. See, c.g., Iow COIE A:z. $\$ 736.2$ (1949). In addition, blacklisting is an unfair labor practice under several state labor relations acts and thus grounds for a suit to require hiring or reinstatement and back pay. See, e.g., MINN. Stat. ANx. $\$ 179.12$ (1946). The criminal statutes vary considerably but they are generally broad enough to cover other blacklists than of union organizers or members.

36. But see Barile v. Fisher, 94 N.Y.S.2d 346 (Sup. Ct. 1949), where the court upheld a denial of a motion to dismiss in an action by an employee against a union for causing him to be discharged. The employee was fired upon his union's request after he refused to pay dues to the union because its officers refused to sign non-communist affidavits. The court held that the allegation that the union caused him to be blaclilisted stated a cause of action. See also the report of the filing of a suit for $\$ 51,750,000$ damages by 22 ex-members of the movie industry against 17 film companies, two producer associations, 20 movie executives, 9 Congressmen on the House Un-Ameriean Activities Committee, and 2 committee investigators; the plaintiffs alleged that they had been made jobless pariahs as a result of having been named on a movie industry blacklist for refusal to answer questions of the Committee, etc. A permanent injunction against "maintaining any blacklist or policy of blacklisting or discriminating against the plaintifis . . with respect to employment in the motion picture industry" was also requested. Time, March 23,1953 , p. 108. 
strong argument can be made that the California-type statute was designed to curb just this type of employer activity. ${ }^{37}$ The mere fact that the minority political beliefs seeking protection today are particularly repugnant should not obviate the application of such statutes. They were designed to protect any employee political activities-so long as they are not criminal ${ }^{83}$-regardless of public antipathy to such beliefs. And the more distasteful the employee's beliefs, the more necessary the statute. Despite the persuasiveness of this argument, however, the California rationale will probably be followed elsewhere if the question arises again. The general attitude of courts toward suspected subversives today is not friendly. ${ }^{39}$ Moreover, the profusion of loyalty measures passed by federal and state legislatures ${ }^{40}$ indicates that an interpretation of such a statute which protected the job of a communist might result in immediate amendment or repeal of the statute.

Even if courts should properly construe such statutes as not protecting from discharge persons who advocate overthrow of the Government by force or violence, ${ }^{41}$ the California court in the Lockheed case went further than neces

37. The purpose of this statute is discussed in Note, 35 Calif. L. REv. 310 (1947).

38. See the lower court decision in Lockheed Aircraft Corp. v. Superior Court of Los Angeles County, 153 P.2d 966 (Ct. App. 1944).

39. See, e.g., note 122 infra.

40. See notes 1 and 2 supra.

Two states have statutes which appear expressly to sanction some private loyalty programs. MONT. REv. CODE $\$ 77-606$ (1947), dealing with reemployment of persons completing military or naval service, provides:

"Policy respecting members of communist party or German-American Bund. It is expressed policy of the legislature of the state of Montana that wherever a vacancy is caused in the employment rolls of any business or-industry by reason of induction into the service of the United States of an employee pursuant to the provisions of said selective training act of 1940 , or the national guard and reserve officers mobilization act stch vacancy shall not be filled by any person who is a member of the communist party or the German-American Bund.”

This provision provides no sanction and it does not appear ever to have been involved in litigation. The Oregon Discriminatory Practice Act, Ore. Consp. Laws ANN. 1028a02 (Supp. 1947), after prohibiting certain types of discrimination states:

"Provided that no one professing or admitting membership in an organization believ" ing in the overthrow of the nation by force need be employed."

Ohio, by an Act of 1949, has declared that persons who advocate or belong to organizations that advocate overthrow of the Government by force or violence are not entitled to unemployment relief. OHro GeN. CODE $\$ 1345-6$ c(4) (Supp. 1950), Dworkin v. Collopy, 56 Ohio Law Abstract 513, 91 N.E.2d 564 (C.P. 1950) (constitutionality upheld). See, also, Emergency Relief Act of 1940, 54 STAт. 611 et seq., 15 U.S.C. $\$ \$ 721-8$ (1948). Compare United States v. Hautau, 43 F. Supp. 507 (D.N.J. 1942), with United States v. Schneider, 45 F. Supp. 848 (D. Wis. 1942).

41. But compare the criticism of this policy by Professor Chafee:

"Driving Communists out of their chosen occupations and putting a stigma on them which makes it almost impossible to obtain any other useful employment will not turn such persons into decent American citizens. Instead, they will be more embittered than 
sary in declaring its statute inapplicable whenever an employee's loyalty is not proven "to the satisfaction of the employer." 42 By merely stating that his reason for discharge is lack of satisfaction with an employee's loyalty, an employer, under this rationale, can coerce conformity with his own political views or abstention from political activity. For example, application of the California Supreme Court's standard would uphold an employer if he in good faith believes that membership in the American Legion or Americans for Democratic Action makes a person's loyalty doubtful. Of course, courts can block such unfortunate results by holding that the claims are not made in good faith. But further restraint is desirable. An employer's reasonableness in suspecting an employee as well as his good faith in holding such belief should be considered. If the asserted grounds for doubt about loyalty take the form of protected "political activity," such belief should be held unreasonable and the statute held violated.

Even so interpreted, such statutes provide scant protection against unwarranted discharge based on suspicions of disloyalty. Most are penal in nature. ${ }^{33}$ And even where a civil action for damages is allowed, the burden of proof is virtually prohibitory. ${ }^{44}$ Only where the employer admits that the discharge is on loyalty grounds, as in the Lockhecd case, is there possibility of success. Unless the statute allows punitive damages, the damages recoverable in a civil action may not be worth the effort. ${ }^{45}$

ever, and they will have no means of keeping alive except to become agitators of a dangerous sort."

Chafee, Thirty-Five Years with Freedom of Spcoch, 1 Kax. L KEv. 1, 15 (1952). For other dissents from the prevailing policy, see, c.g., BARTB, op. cit. supra note 1; O'Brian, New Encroachnents on Individual Frecdom, 66 Hanv. L. Rev. 1 (1952).

42. Lockheed Aircraft Corp. v. Superior Court of Los Angeles County, 23 Cal.2d $481,485,171$ P.2d 21, 24 (1946).

43. See note 24 sispra. The Supreme Court of California held in the Lochlccd case, supra note 42 , that its statute impliedly created a civil right of action. For a recent care discussing whether a civil right of action will be implied from a criminal statute, see Odell v. Humble Oil \& Refining Co., 201 F.2d 123 (10th Cir. 1953).

44. There have been relatively few prosecutions or civil actions under any of these statutes because of the difficulties of proving violations by employers. This problem has been much discussed in connection with fair employment practices legislation. See citations note 14 supra. Enforcement of the various labor relations acts is generally more easily accomplished because administered by boards with broad powers to investigate and hear complaints, because anti-union activities are often more overt, and breause the criminal burden of proof need not be met.

45. See, e.g., Harmon v. United Mine Workers of America, 166 Arl: 255, 265 S.W. S4 (1924) (no damage to employee from discharge from employment terminable at will); Odell v. Humble Oil \& Refining Co, 201 F.2d 123 (10th Cir. 1953) ("Where a contract of employment expressly empowers an employer to terminate the contract upin giving notice, recovery for wrongful breach is limited to the notice period."). But of. Barile v. Fisher, 94 N.Y.S.2d 346 (Sup. Ct. 1949) (damages include loss pending new job). And see note 35 supra. 


\section{FEderal Statutes}

The National Labor Relations Act, as amended by Taft-Hartley, ${ }^{40}$ represents the principal federal restraint on an employer's right to discharge. Although there is nothing in the Act prohibiting an employer from discharging an employee suspected of subversive activity, ${ }^{47}$ the NLRB is given the power to make a factual determination of the actual motive for any discharge. Regardless of the declared motive, if the Board finds that the real reason for discharge is illegal under the Act, the employer may be held guilty of committing an unfair labor practice. ${ }^{48}$

Prior to the Korean emergency the attitude of the National Labor Relations Board toward private loyalty measures might be characterized as one of great suspicion. Before 1950 the defense that an employee was fired because he was suspected of disloyalty was thus closely scrutinized and usually rejected as not the real reason for the discharge in actions for discriminatory firing. ${ }^{40}$

46. 49 STAT. 449 (1935), 29 U.S.C. $\$ 151$ (1946), as amended by the Labor Management Relations Act of 1947, 61 StAT. 136, 29 U.S.C. $\$ 141$ (Supp. 1952).

47. In its Third Annual Report the NLRB stated that it:

“. . has been careful not to interfere with the normal exercise of the right of tho employer to select employees or to discharge them. . . The Board has never held it to be an unfair labor practice for an employer to hire or discharge, to promote or demote, to lay off ... for asserted reasons of business, animosity, or because of sheer caprice, so long as the employer's conduct is not wholly or in part motivated by anti-union cause." 3 NLRB, ANN. REP. 65 (1938).

48. Among the acts declared to be unfair labor practices for an employer aro: to interfere with, restrain or coerce employees in the exercise of their rights to organizc or refuse to organize or to engage in or refuse to engage in concerted activitics for the purpose of collective bargaining or other mutual aid or protection; by discrimination to encourage or discourage membership in a labor organization; to discharge or otherwise discriminate against an employee because he has filed charges or given testimony under the Act. 61 Stat. 140-1 (1947), 29 U.S.C. \& 158(a) (Supp. 1952).

49. See, e.g., Pusey, Maynes \& Breish Co., 1 N.L.R.B. 482 (1936) ; Cincinnati Milling Machine Co., 9 N.L.R.B. No. 46, 3 LAB. REz. REP. (Ref. Man.) 289 (1938), pctition to review dismissed, 102 F.2d 979 (6th Cir. 1939) ; The New York Times Co., 26 N.L.R.B. 1094 (1940) ; Clayton \& Lambert Mfg. Co., 34 N.L.R.B. 502 (1941) ; Franque A. Dickins, 64 N.L.R.B. 797 (1945). Cf. National Labor Relations Board v. Fulton Bag \& Cotton Mills, 180 F.2d 68 (10th Cir. 1950); National Linen Service Corp., 48 N.L.R.B. 171 (1943).

In Cincinnati Chemical Works, Inc., 51 N.L.R.B. 461 (1943), the discharge of a union organizer for making unpatriotic statements was held to be discriminatory whore the employer only superficially investigated and failed to question the employce prior to discharge. But in National Labor Relations Board v. Cincinnati Chemical Works, Inc., 144 F.2d 597 (6th Cir. 1944), the court denied enforcement of the Board's reinstatement order saying:

"We do not conceive that in enacting a law in time of peace for the furtherance of peaceful industrial relations, Congress intended to foreclose the courts of the United Statcs in reviewing Labor Board decisions from functioning even independently enough to protect the nation from the danger of subversive activity in munition plants in time of war. ... We cannot believe that Congress contemplated to set up the Labor Board so high 
But since 1950 a change has occurred. Two administrative rulings of the General Counsel of the Board issued early in $1951^{\mathrm{Eg}}$ demonstrate that an employer now has wide leeway to discharge without fear of an unfair labor practice charge. In both cases the General Counsel stustained regional directors' refusals to issue complaints alleging discriminatory suspensions of employees. Evidence that the employer, in effectuating the suspensions, was motivated by, and acted in good faith reliance upon. belief that the discharged employees were communists was sufficient justification for the refusal.51 Since

above the federal courts that a United States Circuit Court of Appeals in time of war would be compelled to direct the reinstatement in a chemical plant of a distharged employee who, despite a contrary finding by the Board, is believed by this court upon the evidence of record to have stated the day following Pearl Harhor that he hopel the Japs would sink some more U.S. ships. ..." Id. at 59 S-9.

As to widening of the scope of judicial review of NLRB decisions under the TaitHartley Act, see Wolletr, Labor Relations and Feneral Law 24 (1949).

Similar problems could arise under state labor relations acts, see note 22 sifra, but no such case has been discovered.

50. Administrative Ruling of NLRB General Counsel, Case No. 63 (Mrarch 7, 1951), 27 LAE. REL REP. (Ref. MIan.) 1443 (1951); Administrative Ruling of XLRB General Counsel, Case No. 72 (March 30, 1951), 27 Lab. REL. REP. (Ref. Mian.) 1510 (1951). See also Stewart-Warner Corp., 94 N.L.R.B. 607, 633 (1951), order set aside, 194 F.2d 207 (4th Cir. 1952), discussed at length in National Industrinal Co:sference Bo.rod, op. cit. supra note 4, at 64. See Ncw Grounds for Firing, Business Week, Apr. 14, 1951, p. 31 (commenting on the "shift" in NLRB policy and recommending employer action).

51. The suspended employees involved in General Counsel Ruling in Case No. 63,

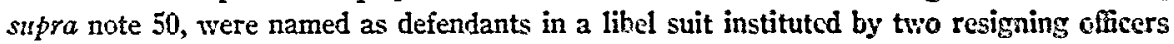
of their own union. The suit denounced the union as communist-dominated and charged the individuals with being members of the Communist Party. Shortly after the institution of the suit the company suspended the complainants and in a letter to them stats: (1) if the charges in reference to their communist affiliations were proved correct it was deemed in the best interests of the company that they be suspended; (2) if the charges were proved false to the satisfaction of the company within one year the empleyces would be reinstated. The company based its belief that the employees were communists both on the charges in the pending libel suit and their past public assuciation with, and participation in the activities of, a number of alleged communist-front organizations.

The facts in the second ruling indicate that an emplojer today has great leeway. In that case the facts as found by the regional director were: the employee in question was expelled from his union following publication in a newspaper of a petition supporting the Stockholm Peace Pledge, which the employee signed, adding the union name aiter his signature. Following this publication the employee's fellow workers demonstrated resentment against him and this caused unrest in the plant. In upholding the denisl of a complaint, even though the union had a security agreement and had requested complainant's discharge (see text accompanying note 59 infra), the General Counsel held:

"[T] he underlying reason for the discharge was the individual's suspacted communist activity, which was resented by the employees and the union, and was a subject of great concern to the employer if only for the reason that it caused considerable unrest among the employees. This alleged activity was, of course, not protected by the Act and a discharge because of it would not be an unfair labor practice" Administrative Ruling of NLRE General Counsel, Case No. 72 (March 30, 1951), 27 LAB. ReI. REs. (Ref. Man.) 1510 (1951). 
there is no appeal from a refusal to act by the General Counsel, ${ }^{62}$ an employer can avoid trial-examiner or NLRB inquiry into an anti-union charge merely by convincing the General Counsel of his good faith belief of the discharged employee's communist ties.

The NLRB also appears particularly solicitous of any employer action claimed justified by federal security regulations. ${ }^{53}$ In one case the Board held that it would not require reinstatement of an employee discriminatorily discharged where it was shown that the Government refused to consent to his employment on its contracts; and it would not require back pay for any time after which the employer had notice of such refusal. ${ }^{54}$ Moreover, a recent General Counsel ruling sustained a regional director's refusal to issue a complaint alleging that a defense contractor had discriminatorily discharged two employees because of union activities, where the employer had fired both after their refusal to answer questions on a federal security questionnaire ${ }^{55}$ which required them to list union memberships. One had also refused to answer a question as to political affilations. The Defense Department subsectuently deleted the question about union membership in the form, and the employees requested reemployment. But the employer's explanation that it did not wish to have in its employ workers who had refused to cooperate with the Government was considered sufficient justification for denying a complaint. ${ }^{\text {to }}$

A recent circuit court opinion, ${ }^{57}$ however, denotes one limitation on the type of activity which an employer may, without committing an unfair labor practice, consider grounds for doubt about an employee's loyalty. In granting enforcement of an NLRB order requiring reinstatement and back pay to employees found to have been discharged discriminatorily, the court held that employees' adherence to a union that had not filed non-communist affidavits as required by the Taft-Hartley Act 58 was not sufficient grounds for atn employer to suspect their loyalty and therefore discharge them.

Another limitation seemingly imposed by Taft-Hartley on an employer's right to discharge for disloyalty is more apparent than real. If an employer is party to a union security agreement he is prohibited from discriminating against an employee for non-membership in the union, unless membership

52. 61 StAT. 139 (1947), 29 U.S.C. \$153(d) (Supp. 1952). See Hourihan v. National Labor Relations Board, 201 F.2d 187 (D.C. Cir. 1952).

53. The various federal programs affecting private employees are discussed note 95 infra.

54. Reeves-Ely Laboratories, Inc., 76 N.L.R.B. 728, 735 (1948).

55. NME Form No. 48 (Aug. 1, 1948), now replaced by DD Form No. 48 (Aug. 1, 1950).

56. Administrative Ruling of NLRB General Counsel, Case No. 339 (July 11, 1952), 30 LAB. Ret. Rep. (Ref. Man.) 1303 (1952).

57. National Labor Relations Board v. Pratt, Read \& Co., 191 F.2d 1006 (2d Cir. 1951).

58. See supra note 7 . 
in the union was denied or terminated for failure to tender dues or fees. Thus, under such a contract, an employer cannot discharge an employee merely because that employee was expelled from or denied admission to the union on grounds of disloyalty. ${ }^{60}$ But this obstacle is easily avoided if the employer makes an individual investigation and evaluation of loyalty in each case; he can then support the discharge directly on grounds of suspected disloyalty rather than non-membership in the union. ${ }^{\circ 1}$

In the light of the history of the National Labor Relations Act, the Board's approach to private loyalty programs appears justified. The Act was designed to provide a wholesome atmosphere for collective bargaining and to prevent employer conduct aimed at discouraging union activity. ${ }^{62}$ Aside from such

59. $\$ \$(a)(3), 61$ Stat. 140 (1947), 29 U.S.C. $\$ 158(a)$ (3) (Supp. 1952). See, in general, Daykin, Union Security Under Taft-Hartlcy. 2 LAB. L.J. 659 (1951).

60. Kingston Cake Co., 97 N.L.R.B. 1445 (1952) (employer guilty of uniair 1abor practice for firing, at request of union, employee expelled from membership in union for refusal to sign a non-communist affidavit). The Board had previously dodged this issue in the case by holding that the employee was technically not subject to discharge, Kingston Cake Co., 91 N.L.R.B. 447 (1950); but its petition for enfurcement of its urder requiring reinstatement and back pay was denied because the employer had acted in good faith in supposing that the employee was subject to discharge, and the case was remanded for consideration of whether the discharge was improper without regard to the technicality. National Labor Relations Board v. Kingston Cake Co., 191 F.2d 563 (3d Cir. 1951). Prior to the Taft-Hartley Act an employer was permitted to discharge an employee who had been expelled from his union for communist adherence on the evidence of such espulsion without being guilty of an unfair labor practice. Gamble-Skogmo, Inc, 75 N.L.R.B. 1068 (1948).

An indicaton of the reaction of employers to the provision of the Act is found in It's Hard to Get Rid of $A$ Comminist, Business Week, Nov. 11, 1950, p. 120. Senator Pat Mrcarran introduced a bill after the Kingston Cake decision to relieve employers of any possibility of liability under Taft-Hartley for discharge of employees who voluntarily retain membership in any organization on the Attorney General's list. S.2548, 82d Cong., $2 d$ Sess. (1952). The bill was in the form of an amendment to the Internal Security Acts of 1950 . It would relieve the employer but not the union of liability for securing a discriminatory discharge. See Note, 29 LAB. REL Rep. (Ref. Man.) 147 (1952).

61. Presumably a union can suggest discharge of an expelled member not beeause of non-membership but because of his communist activities. In such a situation the NLRB would have to investigate the procedures and motive of the employer. If the employer made little independent investigation and acceded to the union's suggestion merely as an accommodation to the union, the Board would probably find unfair discrimination. But if the employer made his own investigation and discharged on the basis of his own findings, the union's information serving only as a tipoff, the Board would be unlikely to find discrimination. See Administrative Ruling of NLRB General Counsel, Case No. 72 (March 30, 1951), 27 LAB. ReI. REP. (Ref. Man.) 1510 (1951), discussed note 51 suspr, where the General Counsel sustained the regional director's refusal to issue a complaint even though the discharge was suggested by the union and a union sceurity agreement was in effect. And see Note, 29 LAB. REL. REP. (Ref. MIan.) 57 (1952).

62. See the findings and declarations of policy in 49 STsr. 449 (1935), 29 U.S.C. $\$ 151$ (1946), and in 61 STAT. 136 (1947), 29 U.S.C. \$ 141 (Supp. 1952). 
protection of rights of organization and representation, the Act left other restraints upon the common-law rights of employers to be determined through the collective bargaining process. Hence, the policy of refusing to issue unfair labor practice complaints where an employer discharges an employee solely on a good faith belief that the individual is disloyal appears entirely defensible. Unions and the NLRB are alert to prevent such grounds from being used as a subterfuge for anti-union discrimination. And beyond anti-union condluct the Act was not meant to go. In fact, Taft-Hartley's provision for non-communist affidavits ${ }^{13}$ by union leaders suggests a congressional policy of instigating the discharge of persons of questionable loyalty from jobs as labor union leaders.

Other federal statutes impose limitations on the right of private employers to discharge. The Railway Labor Act ${ }^{64}$ has provisions similar to Taft-Hartley; special statutes govern the discharge of seamen and provide for damages upon improper discharge $;^{65}$ the Selective Service Act of $1948^{60}$ provides reemployment rights for veterans and prohibits discharge within one year without "just cause." No case has construed any of these provisions in the context of employer loyalty measures. But two complaints ${ }^{67}$ have alleged that the federal antitrust ${ }^{68}$ laws are violated where a whole industry adopts a loyalty program. ${ }^{68}$

Moreover, the criminal ${ }^{70}$ and civil remedy ${ }^{71}$ provisions of the Federal Civil Rights Acts seem on their face to provide some sort of remedy for per-

63. See note 7 supra.

64. 44 StAT. 577 (1926), as amended, 45 U.S.C. $\$ 151$ (1946), 45 U.S.C. $\$ 152$ (Supp. 1952).

65. 46 U.S.C. $\$ 594$ et seq. (1946). These provisions are implemented by Coast Guard Rules and Regulations, 46 CoDE FED. REGs. $\$ 14$ (Supp. 1950).

66. 62 STAT. 614 (1948), 50 U.S.C. App. $\$ 459$ (b) (Supp. 1952), as clarified, 65 Stat. 85, 50 U.S.C. App. $\S 459$ (g) (Supp. 1952). See, also, Exec. Order No. 10308, 16 FED. REG. 12303 (1951) (Improving the Means for Obtaining Compliance with NonDiscrimintion Provisions of Federal Contracts). A fair employment practices clatuse is included in all Government contracts and such a clause is required in all subcontracts.

67. Maltz v. Loew's, cited in Marcus, Civil Rights and the Anti-Trust Lanes, $18 \mathrm{U}$. of Cri. L. Rev. 171, 188 n.94 (1951); The Screen Writers' Guild v. The Motion Picture Association of America, Civil No. 46-165, S.D.N.Y., 1948, dismissed with permission to amend, 8 F.R.D. 487 (S.D.N.Y. 1948). See also, Loew's Inc. v. Cole, 185 F.2d 641, 652 n.11 (9th Cir. 1950) (quotation from Mr. Eric Johnston, President of the Motion Picture Association of America, that one of the reasons why the employers in the motion picture industry had decided not to make an agreement to refuse to employ communists was advice of counsel that they would be violating antitrust laws).

68. Sherman Act, 26 StAr. 209 (1890), 15 U.S.C. \& 1 (1946); Clayton Act, 38 StAT. 731 (1914), 15 U.S.C. $\$ 14$ (1946).

69. For an excellent discussion of this allegation, see Marcus, Civil Rights and the Anti-Trust Laws, 18 U. of CHI. L. Rev. 171, 188 (1951). As to other possible sources of federal power to prosecute violations of civil rights, see ENIERSON \& HADER, op. cit. sitpra note 1, at 85 ; Note, 57 YALE L.J. 855 (1948).

70. 18 U.S.C. $\$ \S 241-2$ (Supp. 1952).

71. 8 U.S.C. $\$ 41$ (1946). 
sons unjustly discharged on disloyalty grounds. ${ }^{72}$ But in fact, as presently interpreted, they offer little protection; and the only suit alleging violation of these provisions by a loyalty program was recently dropped. ${ }^{73}$ Cnder one of these Acts, any person who, under color of law, subjects an individual to the "deprivation of any rights, privileges, or immunities secured by the Constitution and laws" shall be liable for damages to the injured party. And a similar provision subjects such a person to a criminal sanction. ${ }^{75}$ Since an important qualification of both sections is that the deprivation be carried out "under color" of law, however, few private loyalty measures would qualify under these restrictions even if job security were considered a right secured by federal law.

72. For good general discussions of these provisions, see Clarl, A Fedcral Prosccutor Looks at the Cizil Rights Statutes, 47 CoL. L. REv. 175 (1947); Fraenkel, The Federal Cizil Rights Lazes, 31 MrNv. L. REv. 301 (1947); Gressman, The Urthapps History of Cizil Rights Legislation, 50 MICE. L. Rev. 1323 (1952): Sloan, Federal Ciril Rights Legislation and the Constitution, 1 S.C.L.Q. 245 (1949); Comment, Jurisdiction aeter Violations of Cizril Liberties by State Governments and by Private Indiziduals, 39 Mica. L. REv. 284 (1940). Excellent material may be found in E:rersos: \& HASEs, op. cit. stipra note 1, c. 1 .

73. Screen Writers' Guild v. The Motion Picture Association of Ameriez, Civil No. 46-165, S.D.N.Y. 1948, dismissed aith pormissions to anend, S F.R.D. $4 \$ 7$ (S.D.N.Y. 1948). Petitioners' Amended Complaint, pp. 10-11, alleged:

"In the execution of the conspiracy set forth in this complaint the defendants have exercised and if permitted will continue to exercise over this national industry the powers ordinarily exercised by a political state in the following particulars. They have

(a) prepared and adopted a code governing the views, the conduct and the associations of all who write or seek to write screen plays;

(b) reserved to themselves the power to interpret the meaning of that cade, acting in a capacity similar to the enforcing officer of a state;

(c) set up a body acting in capacity similar to a court of law which claims the right to interpret and adjudge the meaning of the code adopted by the combination;

(d) exercised and threatened to exercise judicial power to adjudge what conduct and activity is dangerous to the security of the government;

(e) asserted the right to interpret the Constitution and laws of both the state and the federal governments in order to adjudge whether belief, conduct or associations tend to the overthrow of the government by illegal and unconstitutional means;

(f) asserted the right to carry out and have carried out the decrees of this illegally constituted court by the drastic banishment from the motion-picture industry of any writer condemned by the combination; and

(g) having acquired control, through concerted action, over the livelihood and property of every person writing for the screen is exercising that control as a politioal state would exercise it;

all to the lasting and irreparable damage of the plaintiffs."

74. S U.S.C. $\$ 43$ (1946). This section provides that such a person shall be liable to the injured party "in an action at law, suit in equity, or other proper pruceeding for redress."

75. 18 U.S.C. $\$ 242$ (Supp. 1952). A fine of not more than $\$ 1000$ or impriconment for not more than one year are prescribed as penalties for violation of this provision. 
Another provision of one of the Civil Rights Acts makes it a criminal offense for "two or more persons" to "conspire to injure, oppress, threaten or intimidate any citizen in the free exercise or enjoyment of any right or privilege secured to him by the Constitution or laws of the United States."70 Furthermore, as a remedy for conspiracy to deny certain enumerated rights, an injured party is given an action for damages. ${ }^{77}$ The Supreme Court in Collins v. Hardyman, ${ }^{78}$ however, has restricted the latter provisions to situations where the invasion of rights has been accompanied by "some manipulation of the law or its agencies to give sanction or sanctuary for doing so."70 Moreover, courts consistently interpret the phrase "any right or privilege secured ... . by the Constitution" in the conspiracy sections as protecting only rights of "national

76. 18 U.S.C. $\$ 241$ (Supp. 1952). Fine of not more than $\$ 5,000$ or imprisonment for not more than 10 years, or both, are prescribed punishments.

77. 8 U.S.C. $\$ 47(3)$ (1946). This provision reads:

"If two or more persons in any State or Territory conspire or go in disguise on the highway or on the premises of another, for the purpose of depriving, either directly or indirectly, any person or class of persons of the equal protection of the laws, or of equal privileges and immunities under the laws; or for the purpose of preventing or hindering the constituted authorities of any State or Territory from giving or securing to all persons within such State or Territory the equal protection of the laws; or if two or more persons conspire to prevent by force, intimidation, or threat, any citizen who is lawfully entitted to vote, from giving his support or advocacy in a legal manner, toward or in favor of the election of any lawfully qualified person as an elector for President or Vice-President, or as a Member of Congress of the United States; or to injure any citizen in person or property on account of such support or advocacy; in any case of conspiracy set forth in this section, if one or more persons engaged therein do, or cause to be done, any act in furtherance of the object of such conspiracy, whereby another is injured in his person or property, or deprived of having and exercising any right or privilege of a citizen of the United States, the party so injured or deprived may have an action for the recovery of damages occasioned by such injury or deprivation, against any one or more of the conspirators."

78. 341 U.S. 651 (1951). This case is discussed in Frantz, The New Stupreme Coturt Decisions on the Federal Civil Rights Statutes, 11 LAw. GunlD Rev. 142 (1951) ; Gressman, The Unhappy History of Civil Rights Legislation, 50 Mict. L. REv. 1323, 1356 (1952); Comment, The Civil Rights Act: Ennergence of an Adequate Federal Civil Remedy?, 26 Ind. L.J. 361 (1951). Cf. Thompson, Protection of Prizileges and Immunities of United States Citizens Against Interference by Individuals, 1 DukE B.A.J. 63 (1951).

79. Collins v. Hardyman, 341 U.S. 651,661 (1951). The complaint alleged violation of the first clause of $\S 47(3)$, note 77 sitpra. The Court said: "What we have here is not a conspiracy to affect in any way these plaintiffs' equality of protection by the law, or their equality of privileges and immunities under the law. There is not the slightest allegation that defendants were conscious of or trying to influence the law, or were endeavoring to obstruct or interfere with it." Ibid. But the court left one loophole: "We do not say that no conspiracy by private individuals could be of such magnitude and effect as to work a deprivation of equal protection of the laws, or of equal privileges and immunities under laws." Id. at 662. Justices Burton, Black and Douglas dissented, arguing that the provision created a cause of action in favor of persons injured by private individuals through abridgement of federally created constitutional rights. Id. at 663,664 . 
citizenship";s0 and these rights do not include the right to a job.81 Thus the only possible utility of these Acts to discharged employees would be the criminal conspiracy provision, which prohibits the deprivation of rights given by "laws of the United States." In United States $v$. Wraddell 82 the Supreme Court held that this provision applied where private individuals interfered with a person's right to establish a claim under the homestead acts. Logical extension of this theory would prohibit a conspiracy to deprive a person of his rights under any federal statute, including those restricting the employer's right to discharge. ${ }^{83}$ But the scope of these statutes is so narrow that this additional criminal sanction imposes little restraint on loyalty measures.

Although the Civil Rights Acts in no way explicitly cover problems raised by private loyalty programs, a willing court could, within the framework of present decisions, nevertheless find significant restraints on private loyalty programs in the conspiracy provisions. The rights the Federal Government is constitutionally empowered to protect against private citizens under these provisions have long been narrowly construed. ${ }^{84}$ But the rights of a qualified voter to participate in a federal election or to run for federal office have consistently been protected.85 A conspiracy "to injure, oppress, threaten or intimidate" a citizen in the exercise of these rights could be found in a discharge on loyalty grounds if the finding of disloyalty were supported only by proof of conduct representing legal federal political activity. Morcover, courts could reasonably extend their definition of the rights which Congress can constitutionally protect against interference by private individuals. The Constitution guarantees a republican form of government. ${ }^{80}$ This implies

80. Civil Rights Cases, 109 U.S. 3 (18\$3); United States v. Cruilsshanls, 92 U.S. 542 (1875) ; Slaughter-House Cases, 16 Wall. 36 (U.S. 1872).

81. See Hodges v. United States, 203 U.S. 1 (1906); Ferrer v. Frünton Exhibition Co., 188 F.2d 954 (5th Cir. 1951) ; Love v. Chandler, 124 F.2d 785 (8th Cir. 1942); $c$ f. Tenney v. Brandhove, 341 U.S. 367 (1951); United States v. Wheeler, 254 U.S. 231 (1920) ; Powe v. United States, 109 F.2d 147 (5th Cir. 1940), cert. dessicd, 309 U.S. 679 (1940) ; Bradwell v. State, 16 Wall. 130 (U.S. 1S72) ; Mitchell v. Greenough, 100 F.2d 184 (9th Cir. 1938).

\&2. 112 U.S. 76 (18S4).

83. Commentators agree with this interpretation. See Fonvrz, Tne Co:sriturno: AND CivIL RIgBts 44-5 (1947); Clark, sipra note 72, at 181; Gressman, ssspro note 72 , at 1347 n.74; Rogge, Iustice and Cizil Libcrtics, 25 A.B.A.J. 1030 (1939); Comment, 39 Miren. L. Rev. 284, 296 (1940). Cf. Pennsylvania R.R. System v. Pennsylvania R.R, 267 U.S. 203 (1925); Schatte v. International Alliance, 182 F.2d 15S (9th Cir. 1950). And see the unreported cases discussed in Eurerson \& HABER, op. cit. supra note 1, at 70 .

84. See note 80 supra.

85. Smith v. Allwright, 321 U.S. 649 (1944); Ex parte Yarbrough, 110 U.S. 651 (1SS4) ; Ex parte Siebold, 100 U.S. 371 (1879). Cf. Snowden v. Hughes, 321 U.S. 1 (1944). Other protected federal rights are the right to have a ballot in a federal elcetion fairly counted, United States v. Mosley, 238 U.S. 383 (1915), and to be free from mob violence while in the custody of a federal officer, Logan v. United States, 144 U.S. 263 (1892), and to inform authorities regarding a federal offense. In re Quarles and Butler, 158 U.S. 532 (1895).

86. U.S. Const. Art. IV, $\$ 4$. 
a right of citizens to engage in any legal political activities, federal or state. Discharge because of such political activities could be held an attempt to intimidate the enjoyment of this right. This would prohibit employers from conspiring to discharge on loyalty grounds employees proved only to have participated in protected political activities. Of course, both rationales require holding that discharge from a job to which an employee has no "right" constitutes intimidation. But this is but recognition of reality.

From a practical viewpoint, however, there is little likelihood that the Supreme Court will accept this position. Six justices in the Collins case were unwilling to interpret the civil conspiracy provision as restricting a forcible break-up of a political meeting by a group of private individuals. It is therefore unlikely that they would find that an unsupported disloyalty discharge constituted a deprivation of a federally-protected right. Noreover, even if the statute were explicitly extended to prohibit private loyalty programs, the Court might hold such an extension unconstitutional. ${ }^{80}$

\section{Collective Bargaining Contracts}

Probably the most important present restraint upon employers' freedom to discharge is the existence of collective bargaining contracts. ${ }^{90}$ Almost all such union-negotiated agreements now contain provisions restricting management's power to discharge employees. ${ }^{91}$ Some of these contracts recognize

87. See United States v. Cruikshank, 92 U.S. 542, 552 (1870): "The right of tho people peaceably to assemble for the purpose of petitioning Congress for a redress of grievances, or for anything else connected with the powers or the duties of the national government, is an attribute of national citizenship and, as such, under the protection of, and guaranteed by, the United States. The very idea of a government, republican in form, implies a right on the part of its citizens to meet peaceably for consultation in respect to public affairs and to petition for a redress of grievances."

Referring to these statements, the Court in the Collins case, said: "In the light of the dictum in United States $v$. Cruikshank . . ., we assume, without deciding, that the facts pleaded show that defendants did deprive plaintiffs 'of having and exercising' a federal right which, provided the defendants were engaged in a 'conspiracy set forth in this section,' would bring the case within the Act." Collins v. Hardyman, 341 U.S. 651, 660 (1951). See also Robeson v. Fanelli, 94 F. Supp. 62 (S.D.N.Y. 1950),

88. 341 U.S. 651 (1951).

89. See cases cited in note 80 supra, and United States v. Harris, 106 U.S. 629 (1882), In Collins v. Hardyman, the Court said, "It is apparent that, if this complaint meets the requirements of this Act, it raises constitutional problems of the first magnitude. . .." 341 U.S. 651,659 (1951). The Court dodged these constitutional isstes by holding that the conspiracy alleged was not included under the Act. Cf. United States v. Darby, 312 U.S. 100 (1941).

90. About one-third of the more than fifty million Americans in non-agricultural employment are now unionized. The World Almanac 308, 394 (1953).

91. BNA, Coll. Barg. Negot. and Cont., Contract Clause Finder $\{40: 1$ (1953), See also P-H Union Cont. Serv. $\llbracket 53,520$ (1948); U.S. Bureau Lab. Stat. Bull. No. 908-5 (1948). 
the right to fire as a management prerogative, but allow a discharged employee to appeal management's decision through regular or special grievance procedures. Most, however, limit permitted grounds for discharge. Many of these provisions are vaguely worded to allow discharge only "for cause" or "for legitimate reasons." 92 In such cases an arbitrator or a board must decide upon the filing of a grievance whether management's reasons were sufficient. 03 Thus even the vaguest of these contractual restrictions ameliorates the commonlaw rule by both forcing an employer to state and prove his reason for every discharge and by requiring that such reason not be arbitrary in the estimation of an impartial judge.

Both before and since the Korean War, arbitrators and courts have uniformly agreed that, no matter what the collective bargaining provision, Government security provisions supersede the contract and justify discharge. ${ }^{01}$ This is true despite the fact that most of the federal security programs affecting non-Governmental employees do not require that a person denied clearance be fired..$^{95}$ For example, the contract of a Defense Department contractor

92. BNA, Coll. Barg. Negot. and Conr., Contanct Clause Finner ro $40: 1$ et seq. (1953).

93. See, generally, Chantretrlain, Collectrme Bafgamirio (1951).

94. See, e.g., the statements in Firestone Tire \& Rubber Co. of Cal., 4 Ax. Lu. ARb. Awarns T68,778 (1951) ; Bell Aircraft Corp., 16 Lar. ARm. Rar. 234 (1951) ; Curtiss-Wright Corp., 9 LAB. ARB. REP. 77 (1947); Sperry Gyruscope Co. v. Engineers' Ass'n, 279 App. Div. 630, 107 N.Y.S.2d 800 (1st Dep't), aff'd, 304 N.Y. 5\$2, 107 X.E.2d 78 (1951). See also Lachheed Aircraft Co. v. Superior Court of Los Angeles County, 28 Cal.2d 481, 171 P.2d 21 (1946) ; cf. Consolidated Western Steel Corp.n 13 LaR Arn.

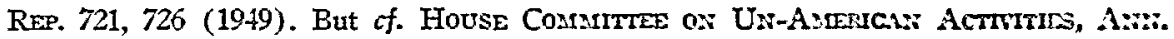
REP. 15 (1951), where it was reported that an employee denied clearance by the Navy was still working on a defense contract because of union cpposition to removal. Further facts were not given but legislation to obviate this situation was recommended.

95. The Federal Government has several security programs that affect non-Guvernmental employment. But to date the primary Government control has been the power to refuse Government contracts. Even to bid on defense or atomic energy contracts an employer needs clearance of his facilities, physical and human. If a contract is awarded it will contain a security clause and the AEC or the Defense Department will retain the right to screen all officers, directors, and owners of the enterprise as well as lvey employees. Any employee coming into contact with classified materials must first be cleared by the government. The clearance procedure involves fingerprinting and filling out a detailed questionnaire which is forwarded to the contracting agency. After investigation the employer and employee are notified of grant or denial of clearance. A person denied clearance generally may appeal to review boards set up for this purpose. These Government agencies can terminate a contract without liability if the employer fails to cooperate in security measures or does not receive clearance on security checl: See Musirions

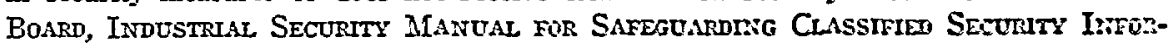
zition (Dep't Def. 1951) ; Munitions Bolrd, How To Be Cleaneo For Huithive Classified Milltiary Inforviation Wrthin Imoustry (Dep't Def. 1951); 10 Cone Fen. REGs. $\$ \$ 4.1-4.20$ (Supp. 1952) (AEC security clearance procedures).

An act of 1926, 4 STAT. 787 (1926), 10 U.S.C $\$ 310(j)$ (1946), restricts cligibility for award of Government aircraft contracts to citizens or corporations with a specificd amount of their capital stock citizen-owned and their board of directors citizens. It further 
provides that only uncleared employees must be denied access to classified information and facilities. And under such a contract, one employee was discharged because he was denied initial clearance by the Army-Navy-Air Force Personnel Security Board on undisclosed grounds. Although the employee was subsequently cleared on appeal to the Industrial Employment Review Board, ${ }^{96}$ the arbitrator held that he was not entitled to an award of pay from the employer for the period he was unemployed. ${ }^{97}$ Thus even this erroneous

provides that no alien shall have access to plans or shall participate in such contracts without clearance from the secretary of the department concerned. In a 1942 memo, Under Secretary of War Robert P. Patterson reconciled this provision with the antidiscrimination clause required in all Government contracts by stating that where there is no doubt of an alien's loyalty the failure of a contractor to hire and cooperate in getting a clearance is a breach and discrimination. P-H LAB. REI. SERv. $\llbracket 36,101.1$ (1946). Sec note 66 supra. A Joint Regulation of the Armed Forces requires in all classified contracts inclusion of a provision that contractors shall, when directed by the secretary of any department, suspend from employment or refuse to employ any person or persons whom the secretary in the interest of security may designate. 32 CODE FED. REGS. \$406.104-12(d) (Rev. 1951).

Article 7 of the standard Government construction contract (U.S. Standard Form 23) has a similar provision. It provides that the contracting officer may require the contractor to remove from the work such employees as the contracting officer deems in* competent, careless, insubordinate, or otherwise objectionable, or whose continued cmployment on the work is deemed by the contracting officer to be contrary to the public interest. 1 CCH, Gov. Cont. REp. $\int 18,201$ (1946). See also Van Knorr v. Miles, 60 F. Supp. 962 (D. Mass. 1945), remanded for dismissal for lack of jurisdiction, 156 F.2d 287 (1st Cir. 1946). Exec. Order No. 10173, 15 FED. REG. 7005 (1950), imposes Governmental security surveillance in certain instances on employees of employers not necessarily contracting with the Government. That order gives the Coast Guard control of security clearance of personnel in the merchant marine and on certain waterfront facilities. Hiring of an uncleared employee for restricted work is a criminal offense, as is retention in such employ after revocation of clearance. See Parker v. Lester, 98 F. Supp. 300 (N.D. Cal. 1951).

The Internal Security Act of 1950, 64 STAT. 987, 50 U.S.C. $\$ \S 781$ et seq. (Supp. 1952), foreshadows even wider scope to federal control of the loyalty of private employees. While not prescribing any affirmative duties for management, the Act provides that the Secretary of Defense shall publish a list of all defense facilities, and that it shall be unlawful for any member of a communist-action organization to hold a job in such facilities. Moreover, it shall be unlawful for a member of any communist-front organization to scek or hold a job in such a facility without disclosing such membership. No list has yet been published, and the Communist Party is presently contesting its designation by the Subversive Activities Control Board as a communist-action organization. See Communist Party of United States v. McGrath, 96 F. Supp. 47 (D.D.C. 1951); 1 SACB, ANs. REp. (1951); EMERSON \& HABER, op. cit. supra note 1, at 579 et seq.; McCarran, The Intemal Sccurity Act of 1950, 12 U. of PITT. L. Rev. 481 (1951) ; Comment, [1951] WIS. L. REv. 704; Note, 51 CoL, L. Rev. 606 (1951); note 121 infra.

96. The IERB was the board of last resort to an employee of a Defense Department contractor denied clearance; this whole review system, however, was recently discontinued by the new Secretary of Defense, Charles E. Wilson.

97. Bell Aircraft Corp., 16 LAB. ARB. REp. 234 (1951). The contract in this case provided that the aircraft manufacturer could take any reasonable action to comply with 
determination by a Governmental agency that the employee was a poor security risk was viewed as sufficient justification for dismissal.

The attitude of arbitrators toward the right of employers under "good cause" contracts to discharge-on grounds of suspected disloyalty-employees who are not subject to Governmental screening has roughly paralleled the attitude of the NLRB and its General Counsel. The weight of decisions prior to 1950 was against allowing discharge in such situations. Four of the six reported cases held against the employer.98 And one of these decisions was sweeping in its conclusions. 9 The arbitrator held that the company could not discharge an industrial employee for membership in or sympathy with the Communist Party since it had not been shown that the employee had committed acts of sabotage or that any real security problem arose from his continued employment. He went on to say that it is not a crime to be a member of an organization listed by the Attorney General, and that a man is entitled to earn a living, even though he subscribes to a theory of government or economics that the company deplores, so long as he is acting within the law. Noreover, in one of the pro-employer decisions ${ }^{109}$ an arbitrator held that a company could not discharge an industrial employee mercly for his refusal to testify before a grand jury investigating subversion, even though the company thought this made the employee's loyalty doubtful. The arbitrator felt that the company had no right to make a decision as to loyalty. Since the charge was so grave, the employee was entitled to legal safeguards not present in an employer's action. But the arbitrator held that the employee could be discharged for missing work while serving time in jail for contempt, since missing work without leave was a justifiable ground for discharge. Two of the pro-worker decisions involved industrial employees accused of distributing communist literature, ${ }^{101}$ and the third involved a social service employee who was allegedly slanting her reports to promote left-wing politics. ${ }^{102}$ The arbitrators in all three of these cases felt the penalty too severe for the facts shown.

security obligations to the Government. After noting that the union had attempted to get information about the grounds for initial screening from both the Air Afateriel Command and the IERB but had failed, the arbitrator declared: "Here again the Panel greatly regrets that the Government Agencies refused to divulge such information. But the Panel is powerless to do anything about such a situation." Id. at 237. The board refused to find that reasonable action by the employer would hare required finding non-restricted employment for the employee pending his appeal.

98. Foote Bros. Gear \& Miachine Corp., 13 Lab. Ann. REp. 848 (1949); CurtissWright Corp., 9 LAB. Arb. Rep. 77 (1947); Spokane-Idaho Mfining Co, 9 Lad. Arn. Rep. 749 (1947) ; National Council of Jewish Women \& Social Service Employees Lonal 19, 2 Axs. LaB. ARb. Awards $\llbracket 67,772$ (1947).

99. Foote Bros. Gear \& Machine Corp., 13 LAR. ARB. Rep. $84 \$$ (1949).

100. Consolidated Western Steel Corp., 13 LAB. ARB. Rep. 721 (1949).

101. Curtiss-Wright Corp., 9 LAB. ARB. ReP. 77 (1947); Spolane-Idaho Mining Co., 9 LAB. ARB. Rep. 749 (1947).

102. National Council of Jewish Women \& Social Service Employecs Loeal 19, 2 Aur. LAB. ARB. Awards $\{67,772$ (1947). In this case the employee was reinstated with- 
In the other pre-Korea case, decided for the employer, the arbitrator did not base his decision squarely on disloyalty. A newspaper had published reports that an industrial employee was a member of the National Committee of the Communist Party under an alias, and that he was active in soliciting party membership in the city. The company contended that these reports had led to unrest and dissension in the plant with a consequent loss of production; and it presented a petition from fellow employees protesting working with the alleged communist. The arbitrator held that under the discharge "for legitimate reason" provision the company was not required to retain an employee who caused unrest in the plant. ${ }^{103}$

In four of the five cases reported since 1950 involving the clischarge of suspected subversives under general contract provisions, the employers have been upheld. ${ }^{10 .}$ And in the other case the disloyalty charges were apparently a

out back pay on the theory that both employer and employee were at fault. The arbitrator found that the employee had not been adequately trained for her job, did not have adequate supervision or leadership, and had never been corrected or warned. And while he stated that the "Council has the indisputable right to avoid subversion of its policies," he also noted that "this area secretary has not been charged and is not found to be a Communist. She has sworn her complete loyalty to the United States and to its democratic princples. ..."

103. Jackson Industries, Inc., 9 LAB. ARB. Rep. 753 (1948). The union defendecl on the ground that if the employer were allowed to discharge on the basis of unsupported charges of disloyalty the job security of all employees was endangered. The arbitrator noted that if the charges were false the discharged employee had a remedy in a suit for defamation. "If they were true, so that he is without a remedy in the courts, then the loss of his job was brought about as a natural conseguence of his own voluntary acts, which he might reasonably have foreseen would produce just such a result. The rights of freedom of thought and of speech are valuable rights, but no company is under a duty to protect those rights at the sacrifice of its existence." Id. at 754.

104. Firestone Tire \& Rubber Co. of Cal., 4 AM. LAB. ARB. Awards $\{68,778$ (1951); Publishers' Ass'n of New York City, 19 LAB. Arb. Rep. 40 (1952) ; Publishers Printing Co., New Haven Evening Register, Oct. 8, 1952, p. 25, col. 3; Los Angeles Daily News Co., 19 LAB. ARB. REp. 39 (1952). See also the two decisions following the visit of the House Un-American Activities Committee to Detroit in 1952. Chrysler Corp., ChryslerJefferson Plant, 19 LAB. ARB. REP. 408 (1952), did not involve a discharge but the loss of part of a day's pay. The employee had been sent home by management because they thought his presence in the plant would cause trouble since he had been named as a communist at one of the hearings of the Committee. The employee involved denied in writing that he had ever been a communist and management made no allegation of disloyalty. The arbitrator held that the employee must be paid for the time he lost because to sustain the employer's action would result in imposing a penalty "not against those who may threaten trouble or interference with production but against an employee who was willingly and properly performing his job." Chrysler Corp., Dodge Main Plant, 19 LAע. Aru. REP. 221 (1952), involved discharge of a person named before the Committec as a communist. The employee, a union leader who had signed a non-communist affidavit, was discharged for distributing literature denouncing the Committee in the plant. The arbitrator held that discharge was too severe a penalty in view of the employer's previous laxity in enforcing its rule prohibiting distribution of literature in the plant. The employce's action was felt to merit severe penalty, however, since as a union official she must have known 
subterfuge to eliminate an active union organizer. ${ }^{105}$ Three of the pro-employer cases involved newspaper employees, ${ }^{100}$ and the other involved an employee in a defense plant. ${ }^{10 z}$

The Los Angeles Daily Neais arbitration. ${ }^{103}$ decided by a five-man arbitration board, is the most recent of these cases. Two members of the newspaper's editorial staff were named by former communists testifying before the House Un-American Activities Committee as their one-time fellow members. Both men refused either to affirm or deny the charge. As a result, the employer fired one and refused to rehire the other, who had not been worling but was on the rehire list when the charges were made. The local union ${ }^{103}$ pressed the employees' grievance and insisted upon arbitration on the ground that the discharge and failure to rehire were not for "just and sufficient cause" as required by the collective bargaining agreement. But a majority of the arbitration board upheld the employer on the theory that a newspaper has a "quasi-public responsibility" and that management thus "has a right to expect its employees who are so accused to answer these charges." Because of the refusals of the two employees to refute the charges, unfarorable public opinion could cause the employer severe financial loss if it did not take action to instill public confidence in its policies. ${ }^{110}$

This decision goes further than any other reported arbitration in holding the factors present sufficient to justify discharge. The arbitrators explicitly ruled that nobody had proved either of the two editors to be a communist; and the publisher admitted that the one who was working was very able and

of the no-distribution rule, and that the controversial literature she was distributing vould incite trouble. The discharge was therefore reduced to six months' layoff without pay and without accumulation of seniority or other rights.

105. Cutter Laboratories, 15 LAB. ARR. REP. 431 (1950), aff'd ssb nom. Cutter Laboratories v. Bio Lab Union, 16 LAR. ARR. Rep. 208 (Cal. Super. Ct. 1951). Although there was some evidence in this case that the discharged employee was a member of the Communist Party, the arbitrator found that the employer knew this for over two years and had thus waived it as a ground for discharge. Mforeover, the discharged employee was a union officer at the time of her discharge and the employer was in the midst of a dispute with the union.

106. See note 104 supra.

107. Firestone Tire \& Rubber Co. of Cal., 4 Ass. Lab. Arb. Awaros 969,778 (1951).

108. 19 LAB. ARB. REp. 39 (1952). See Editor and Publisher, Aug. 16, 1952, p. 9; Time, Sept. 1, 1952, p. 48.

109. The American Newspaper Guild. It found itself in a somewhat anomalous position since it had recently fought hard to fire communists from its own paid jobs. Ibid.

110. The board divided 3-2 with impartial arbitrator, Paul A. Dodd, Dean of Letters and Science at U.C.L.A., breaking the union-management deadlock Dodd vrote that "the Publisher, in self-defense against anticipated serious financial repercussions brought on by unfavorable public opinion, has the right under the terms of the worling agreement to ask and expect those accused to clear themselves of the serious charges made under oath against them, if they are to continue their employment with the Publisher. . . ." Los Angeles Daily News Co., 19 LAB. ARb. Rep. 39 (1952). 
had never "slanted" his copy. But the nature of their jobs made the doubts raised by refusal to testify sufficient to warrant discharge.

In the other recent discharge cases, management has been able to produce more substantial proof of both disloyalty and injury. Thus one of the printers whose dismissal was upheld admitted to having been a communist and was found to have distorted the text of an article to reflect the communist line; ;11 $^{11}$ the other printer was found to have neglected his duty while participating in pro-communist activities. ${ }^{12}$ And the industrial employee was found to have made repeated disloyal statements to fellow employees on company time and thus to have abused his "captive audience."113

These cases involving discharge of employees suspected of disloyalty under "good cause" contracts are too few in number to provide a basis for very extensive generalization on the attitude of arbitrators and courts. The decisions both before and since the Korean War suggest, however, that in any situation in which the employer suffers actual injury through retaining in his employ a person of questionable loyalty, the employer has "good cause" for the discharge. Thus unrest in the plant, loss of consumer patronage, or damage to equipment appears to be sufficient justification. But the post-1950 opinions, all of which involved relatively sensitive jobs, seem somewhat more willing to find such injury than did those prior to that time. And in the Daily Nezws arbitration, the arbitration panel appeared to feel that potential injury to an employer was enough. Since a failure to act promptly to eliminate persons of questionable loyalty from key positions on his staff might destroy public confidence, the employer was justified in acting immediately even though there was relatively little evidence of disloyalty. ${ }^{114}$ The decisions allowing discharge where Government security clearance is denied accord with this rationale that potential damage, based on reasonable grounds for doubting loyalty, is sufficient. In fact, the very theory of the security programs is the denial of clearance to persons who are potentially dangerous to the facilities. ${ }^{115}$

111. Publishers' Ass'n of New York City, 19 LAB. Arb. Rep. 40 (1952). The printer was found to have substituted the phrase "American system of facism and security" for "American system of freedom and security." The board found that the substitution was "too pat to suggest error; on the contrary, its very aptness suggests willful substitution," and that "the type as set represented a disloyal distortion of text in defiance of the spirit and sense of the article in question. Whether it was deliberately done by Ross or was the inadvertent or subconscious response of his communistic distaste for the subject matter it demonstrated his unsuitability for continued employment."

112. Publishers Printing Co., New Haven Evening Register, Oct. 8, 1952, p. 25, col. 3. Discharge was upheld on the theory that the employee neglected his duty by participat. ing in pro-communist propaganda while vacationing in Europe, and by repeating antiAmerican propaganda of the communists in speeches before groups of laborers.

113. Firestone Tire \& Rubber Co. of Cal., 4 AMr. Lab. Arb. Awards $\llbracket 68,778$ (1951).

114. See note 110 supra. Cf. Chrysler Corp., Chrysler-Jefferson Plant, 19 LAv. Akw. REP. 408 (1952), discussed note 104 supra.

115. See note 95 supra. 
The question of whether or not mere membership in the Communist Party would constitute "good cause," absent any showing of injury, however, remains somewhat in doubt. Arbitrators in several of the pre-1950 cases refused to allow discharges purely on that basis, pointing out that the Communist Party had not been outlawed. ${ }^{110}$ And one case suggested that although disloyalty might be sufficient cause for discharge, only the Government has a right to prove such disloyalty. ${ }^{117}$ But the Internal Security Act of 1950118 and the prosecutions under the Smith Act ${ }^{110}$ indicate a shift in public policy toward the American Communist Party. Moreover, one state ${ }^{120}$ actually has outlawed that organization; and the Subversive Activities Control Board recently branded it a "subsidiary and puppet of the Soviet Union."121 Therefore, it is possible that arbitrators today might equate membership in the Communist Party with disloyalty and hence allow discharge without proof of injury or prospective injury. ${ }^{122}$ Yet, in point of fact, such a case is not

116. Foote Bros. Gear \& Machine Corp., 13 LAB. ARB. Rep. \&4S (1949).

117. Consolidated Western Steel Corp., 13 LAB. Arb. REp. 721 (1949).

118. See note 95 supra.

119. See, e.g., Dennis v. United States, 341 U.S. 494 (1951).

120. Georgia. See N.Y. Times, Feb. 24, 1953, p. 27, col. 8; id., Feb. 26, 1953, p. 10, col. 7.

121. New Haven Evening Register, April 20, 1953, p. 1, col. 2. The members of the board unanimousiy agreed that the party "is substantially direeted, dominated and controlled" by Russia.

122. An insight into the attitude of courts toward discharge on disloyalty alone can be gained from the only reported case involving discharge under individual employment contracts. This case involved the "Hollywood ten" and a provision of their contracts under which each agreed:

"To conduct himself with due regard to public conventions and morals and agrees that he will not do or commit any act or thing that will tend to degrade him in suciety or bring him into public hatred, contempt, scorn or ridicule, or that will tend to shoels, insult or offend the community or ridicule public morals or decency, or prejudice the producer or the motion picture, theatrical or radio industry in general." Cole v. Loew's Inc., \& F.R.D. 50S, 513 (S.D. Cal. 1948).

Four of this group, who had refused to answer questions by the House Un-American Activities Committee as to whether they were or had ever been communists and were discharged for such conduct, sued for damages for breach of contract. L'gon a motion by the employer for pre-trial examination of plaintiffs a California court ruled that questions relating to plaintiffs' conduct as lawful grounds for discharge were permissible. Moreover, the court ruled that for an employee to be, or to refuse to deny being, a communist is sufficient ground, as conduct detrimental to an employer's business, to justify the employer in discharging such employees prior to the termination of his contract of $\mathrm{cm}$ ployment. The court based this conelusion on reasoning that being a communist is defamatory per se in California, that the Communist Party is not a recognized political party in California, and that a person who is unwilling to state publisly whether he is or is not a communist is regarded as a communist. Cole v. Loev's, Inc., $16 \mathrm{CCH}$ LAD. CAS. $\pi 64,974$ (Cal. Super. Ct. 1949).

Before this decision was reported defendant removed the case to the Federal District Court for the Southern District of California. See 76 F. Supp. $\$ 72$ (1948) (defendant's challenge of judge orerruled). After a trial by jury it was held that no cause 
likely to arise. Often an employer can show actual injury resulting from employment of a publicly known communist. And if a showing of potential injury is accepted as constituting "good cause," virtually any discharge of a known communist might be so justified.

Evaluation of possible approaches to disloyalty discharge under collective bargaining contracts presents an extremely difficult problem. On the one hand is the persuasive argument that all men, regardless of their political beliefs, should be entitled to earn a living. ${ }^{123}$ And there are few employment opportunities open to a man who has once been discharged on an employer's suspicion of disloyalty. Furthermore, suspicions of disloyalty are often groundless. Many individuals innocently lend their names to subversive groups without realizing the true nature of the organization. ${ }^{124}$ In recognition of the latter situation, the Supreme Court has recently ruled that knowledge of the nature of such an organization is a constitutional prerequisite to an oath which conditions public employment upon a disavowal of membership in any such group..$^{125}$

On the other side of the scale are considerations affecting the interests of the employer and the public. Certainly the national security should not be endangered by a self-righteous solicitude for individual freedom of expression which forces a private employer to retain a person of doubtful loyalty in a key position. Nor does it seem proper that an innocent employer should be forced to suffer economic injury resulting from the outside activities of his employees. If advocacy of unpopular beliefs is to cause substantial losses, such losses should fall upon those who can accept or avoid that risk rather than upon an innocent third party. Furthermore, mere membership in the Communist Party is highly offensive to public mores. A policy which forces

for plaintiff's discharge existed, and he was awarded damages for all lost employment in the amount of $\$ 78,400.8$ F.R.D. 508 (1948). The Ninth Circuit reversed this decision because of improper instructions to the jury, particularly in allowing the jury to decide whether Cole had a right under the contract to refuse to answer questions of the House Committee. They held that one who conducts himself so as to be guilty of the misdemeanor of contempt of Congress could not be said to be acting "with due regard to public conventions." Since they could not uphold the verdict as a matter of law, the Ninth Circuit remanded the case for a new trial. In so doing the court stated that the employer would have been well within his rights in discharging plaintiff if he were at Communist. Loew's, Inc. v. Cole, 185 F.2d 641 (9th Cir. 1950), cert. denicd, 340 U.S. 954 (1951). It has since been informally reported to the editors of this JounNal that the litigation was settled out of court prior to a second trial.

123. See note 41 supra.

124. See House Commitree on Un-American Activities, Ann. Rep. 3 (1952): "An examination of the testimony of a large group of these witnesses conclusively reveals that they did not join the Communist Party to participate in any action designed to overthrow the United States. They joined in some instances to defeat Hitler, or support labor, and it was only long after their association with the Communist Party that they learned the true intent and purpose of this organization."

125. Wieman v. Updegraff, 344 U.S. 183 (1952); see Brown \& Fassett, Layalty Tests for Admission to the Bar, 20 U. of CHI. L. REv. 480, 486 (1953). 
an employer to retain an active communist on his payroll purely on the basis of a "good cause" contract may go far beyond the intention of the parties who framed that agreement.

The various policy considerations affecting disloyalty discharge under "good cause" contracts indicate that no clear rule can be established to cover all cases. In view of the fact that the major purpose of the collective bargaining contract is to promote freedom from arbitrary employer action, probably the best that can be hoped for is an impartial balancing of interests in each case. Actual substantive injury to the employer or public, or a real probability of future injury, based upon reasonable doubt as to loyalty, should probably constitute "good cause" under almost any circumstances. Less clear is the question of whether mere membership in the Communist Party, without any reasonably anticipated injury, should also be "good cause." A major problem in all cases, however, is one of marking out proper standards of proof. Should membership in the Communist Party be equated to disloyalty and hence relied on as a basis for discharge, it would seem proper for the arbitrators to place a rather heavy burden of proof upon the employer to prove such membership. The proof of injury required, however, should probably be based upon a reasonableness test-sufficiently flexible to take account of important variables. Using such a standard, the arbitrator can give appropriate weight to the nature of the job, the grounds for suspicion of disloyalty, and the degree of actual or potential injury involved. When such a balancing of interests indicates that the discharge is not arbitrary but is based upon sufficient evidence of injury to satisfy a reasonable man, a finding of "good cause" within the meaning of the contract limitation should be entered.

To decrease the problems involved in discharging suspected personnel under vague contract provisions, employers are increasingly seeking to include in their agreements explicit provisions allowing discharge of suspect employees. ${ }^{126}$ These provisions vary considerably in their breadth depending upon the attitude of the employer and the resistance of the union. ${ }^{127}$ Although few pro-

126. National Industrial Conference Board, op. cit. sispra note 4, at 67 ; U.S. Bureau of LAB. Stat., op. cit. suffra note 91, cl. 25; BNA, Coll. Barg. Nexor. nitd Cont., Contract Clause Finder T 40:14 (1953) ; 1 BNA, Lab. Pol arod Prace $126: 590$ (1953). Cf. Standard Generator Service Co. of Mo., Inc, 90 N.L.R.B. 790 (1950) (insistence on requirement of anti-communist and anti-socialist oath from all union leaders held to evidence bad faith bargaining by the company).

127. See, e.g., the provision in the agreement between the A.F. of L. Chemical Workers and Southern Counties, Cal., Gas Co.:

"Any of the following shall constitute causes for demotion, discharge or disciplinary lay-off, except that advocacy of the overthrow of the government by force and violence, or commission of or conspiracy to commit any act of sabotage, or to engage in any subversive activity, shall be an immediate cause of dismissal: [list omitted]...."

BNA, Coli. Barg. Negot. and Cont., Contract Clause Finder [ $40: 14$ (1953). The Utility Workers (CIO) and the Consolidated Edison Company in 1949 negotiated a contract with a provision that all job applicants must state in their applications whether they belong to "any Communist or other subversive organization." Under this provision 
visions have been construed by arbitrators or courts as yet, ${ }^{128}$ in at least one case a court upheld a provision making discharge non-arbitrable where security clearance was denied; and it granted a permanent stay of arbitration. ${ }^{120}$

all employees are required to notify the company and the union if they join such organization later, and then-present employees were required to take a loyalty onth. Note, 23 LAB. Rel. REP. (Ref. Man.) 8 (1949). Stewart-Warner Corp. and the Int'l Brotherhood of Electrical Workers (A.F. of L.) included a provision in 1950 to the effect that it is the policy of the company not to hire or retain communists in its employ, and that the employer is permitted to require a non-communist oath from applicants or employees. Note, 26 Lab. ReL Rep. (Ref. Man.) 14 (1950), On May 7, 1952, the United Auto Workers and Curtiss-Wright Corp. negotiated an agreement with the following provisions:

"215. In the event that the United States Air Force or any other government agency concerned with security regulations applicable to the Employer advises the Employer to restrict any member of the Union from work on or access to classified information or material, the Union and the International will not hold the Employer responsible for such action as it (the Employer) may reasonably take to comply with its contractual obligations to the Government.

"216. Any claim that the Employer has acted improperly in attempting to comply with the law pertaining to security or with its security agreements with the Government shall be subject to the grievance procedure and arbitration provisions of this Agreement.

"217. The Union and the International recognize that the Employer has certain obligations under the law pertaining to security, and in its contracts with the Government as required by the security regulations of the armed services, and agree that nothing contained in this Agreement is intended to place the Employer in violation of such law pertaining to security or its security agreements with the Government."

Curtiss-Wright Corp. (Wright Aero. Div.) and Local 300, Int'L Union United Automobile etc., Workers, CIO, Agreensent, (1952). See also the reference in Com:munists on the Job, Fortune, Sept. 1950, p. 47, to the fact that Wright Aeronautical Co. was unable to negotiate a clause allowing it to fire subversives without consulting the union. The union stated that it would not oppose Government ordered firings; but it also stipulated that claims of improper company procedure be taken up under contractual griev* ance and arbitration provisions. And see the provisions in the contracts involved in Clayton \& Lambert Mfg. Co., 34 N.L.R.B. 502, 529 (1941); Bell Aircraft Corp., 16 LAD. ARB. Rep. 234, 235 (1951).

128. But see note 122 supra.

129. Sperry Gyroscope Co. v. Engineers' Ass'n, 279 App. Div. 630, 107 N.Y.S.2d 800 (1st Dep't), aff'd, 304 N.Y. 582, 107 N.E.2d 78 (1951). The proceeding to stay arbitration was originally heard by the Supreme Court for New York County. The agreement permitted arbitration of all disputes arising out of the interpretation or application of the contract provisions. It also provided that the discharge of any employee who failed to be cleared by the proper Government security agencies was not arbitrable. An cmployee who was assigned work on a confidential project sought clearance. When no action was taken on his request for seventeen months, he was suspended by the employer. The union demanded arbitration, but the employer moved to stay arbitration on the ground that the failure of the armed forces to make any determination for such an extended period justified the employee's discharge without recourse to arbitration. The lower court denicd the motion for a stay on the ground that there was a bona fide dispute about the meaning of the contract provision as applied to the employee in question which shoult the determined by the arbitrator. Sperry Gyroscope Co. v. Engineers' Ass'n, 106 N.Y.S.2d 597 (Sup. Ct. 1951). By the time the appeal was heard by the Appellate Division cleat"ance of the employee involved had formally been denied by the Government. The Appel- 


\section{Conclusions}

There are few, if any, real restrictions on private employer loyalty measures today. Courts are not inclined to interpret existing statutes so as to restrain such programs. Arbitrators also are increasingly upholding discharges of suspected subversives where the employer's action is not arbitrary. And the NLRB is apparently no longer suspicious of all disloyalty discharges.

Most discharges based on suspicion of disloyalty are probably effectuated without any disclosure of their true nature. ${ }^{130} \mathrm{~A}$ majority of the employees in this country are not protected by collective bargaining contracts ${ }^{131}$ or the $\mathrm{Na}$ tional Labor Relations Act. ${ }^{132}$ Employers firing such employees need not disclose the reason for their action, except in nine states which require an employer to give a discharged employee a statement of his service and the reason for his discharge. ${ }^{133}$ And even in such states an employer can always find a plausible ground for discharge. Moreover, even where there is an active union, management is undoubtedly able by using some subterfuge to eliminate unwanted employees without publicizing the real reason for discharge. ${ }^{134}$ Unions themselves have been known to condone or assist management in easing out suspect employees. ${ }^{135}$ In all such cases where the reason for the discharge is not publicized, the harm to the individual is no greater than if he had been fired because his employer did not like the color of his hair.

But where doubts as to an employee's loyalty as a ground for discharge are publicized, the employee suffers harm beyond the loss of his job. Most employers will not knowingly hire an employee discharged elsewhere on sus-

late Division reversed and granted a permanent stay of arbitration holding that the changed facts made the discharge justifiable and not arbitrable.

130. See, e.g., National Industrial Conference Bondo, op. cit, supra note 4, at 63 :

"Where the union is cooperative or where there is no union, companies report that the best thing to do is to fire men of questionable loyalty. Communist aftiliation is rarely used as the premise since this may be difficult, if not impossible, to prove legally. Instead, an infraction of company rules, submission of a false employment application, or failure to perform work satisfactorily are generally the bases of dismiscal. Some companies report, however, that, 'Commies can be awfully good and conscientious wirlsers when the beat is on.'

"Security personnel maintain, however, that in the long run, with vigilance and careful 'bookkeeping' of the actions, comings and goings, absences, vacation leaves and any violations of these or of other company rules, management will be able to get rid of some of its security risks. ..."

131. See note 90 supra.

132. The power of the NLRB to prevent persons from engaging in uniair labor practices is limited by $\$ 10$ of the Taft-Hartley Act to such practices "affecting commeree." 61 STAт. 146 (1947), 29 U.S.C. $\$ 160$ (Supp. 1952).

133. Fla., Iowa, Ky., Mo., Mont., Neb., N.MI., Ot.la, Texas. Several of these statutes are very limited. See, e.g., OnLA. Stat. AnN. tit. 40, $\$ 171$ (1937). Cf. Mo::t. Rn. Covz tit. $41, \$ 1311(1947)$.

134. See note 130 sugra.

135. See, e.g., National Industrial Conference Bo.ro, op. cit. silpro note 4 , at 65 et seq.; Fortune, Sept., 1950, p. $4 \mathrm{~S}$. 
picions of disloyalty, even though they have no idea of the basis for the suspicions. ${ }^{136}$ And the employee may be stigmatized without ever having a chance to defend himself. Of course, a party unjustly injured by such a program may bring an action for defamation against the employer. But such an action is extremely difficult to win. ${ }^{137}$ Moreover, the expense of a defamation action is apt to make this remedy unavailable or undesirable to most employees.

There are other real dangers of abuse in allowing employers free rein with such measures. Management may employ such a program to circumvent contractual or statutory protections of workers' jobs. And employers can use such measures to stifle legitimate political views not consistent with their own.

Perhaps other restrictions should be placed on such employer action. There are, of course, various types of restraints that theoretically could be imposed. But it is inconceivable that any legislature today would prohibit discharge by private employers on grounds of disloyalty. To deny to private employers the right to exercise their own discretion as to the employment of suspected subversives while insisting that no suspected subversives be retained in Government employ would be somewhat inconsistent. And it is also most unlikely that any legislature would circumscribe the employer's common-law right by declaring it a crime, an unfair labor practice, or a ground for a punitive damage action to discharge on grounds of disloyalty without reasonable proof of such disloyalty. Deeply rooted in American society are the concepts that employers are free to select their own employees; that employment conditions are subject to contract and that, absent contract, employment is terminable at will; and that the availability of a defamation action is adequate protection to individuals against unjust accusations. These factors, viewed in a context of the nation engaged in a global struggle with a foe that has proved its mastery of subversion, make reluctance to enact such restrictive leglislation understandable. Since legal restriction is thus impractical and possibly undesirable, the future of loyalty discharges rests in the hands of the individual employers. Except for contractual limitations, self-restraint, springing from a moral realization of the human impact of discharge for suspected disloyalty, appears the only feasible restriction upon employers' actions.

136. See the remarks of Professor Chafee, note 41 supra. A discharged employee might not even be able to collect unemployment relief. See note 40 supra.

137. See notes 18 and 19 supra. 